\title{
TEMPORALITIES EMBEDDED ON THE INTENSIVE BODY DURING THE EXPERIENCE OF THE ARTISTIC PROJECT SOUNDSYSTEM
}

\author{
Priscilla Porto Nascimento Fasani
}

\begin{abstract}
This article addresses the artistic project SoundSystem, developed by Franz Manata and Saulo Laudares since 1996. The process, in action up to the present day, consists of sharing experiences through sound installations, DJ's performances and urban interventions. Universal signs such as heart beats and bird corners are used. The duo assumes an ethical concern to affect the participant. The main issues involved are the "good encounters", the time-dilation and the intensity provoked by the dionysian impulses of music and dance. This text will discuss the possibility of experience the time of the event, resisting to chronopolitics.
\end{abstract}

\section{TEMPORALIDADES INSCRITAS NO CORPO INTENSIVO DURANTE A EXPERIÊNCIA DO PROJETO ARTÍSTICO SOUNDSYSTEM}

\section{RESUMO}

Este artigo debruça-se sobre o projeto artístico SoundSystem, desenvolvido por Franz Manata e Saulo Laudares desde 1996. O processo, em ação até os dias de hoje, consiste em partilhar experiências através de instalações sonoras, performances de DJ's e intervenções urbanas. São utilizados signos universais como batidas de coração e cantos de pássaros. A dupla assume uma preocupação ética de afetar o participante. As principais questões envolvidas são os "bons encontros", a dilação do tempo e a intensidade provocada pelos impulsos dionisíacos da música e da dança. Neste artigo, a proposta é viver o tempo do acontecimento, resistindo à cronopolítica. 


\section{INTRODUCTION}

In this article, we will consider the practice of constructing a body without organs through the experiences shared by the artists Franz Manata and Saulo Laudares in the works Heartbeat (2006), The Place (2010) and AFTER: Nature (2008). These sound installations were exhibited in Rio de Janeiro: in Parque Lage, in the house of curator Bernardo Mosqueira and outdoors, at Aterro do Flamengo, respectively. The intensive sensations that can be felt during these exhibitions, provoke changes in the circuits of affections, which allow the creation of a dancer body, which also dances inside out. The artists resist chronopolitics and propose a time of the event. Dance and music allow the body to be freed from its utilitarian and organic movements. This logic of sensation happens in these encounters that link the artistic processes to the vital processes, provoking the invention of other times, different from the chronological time.

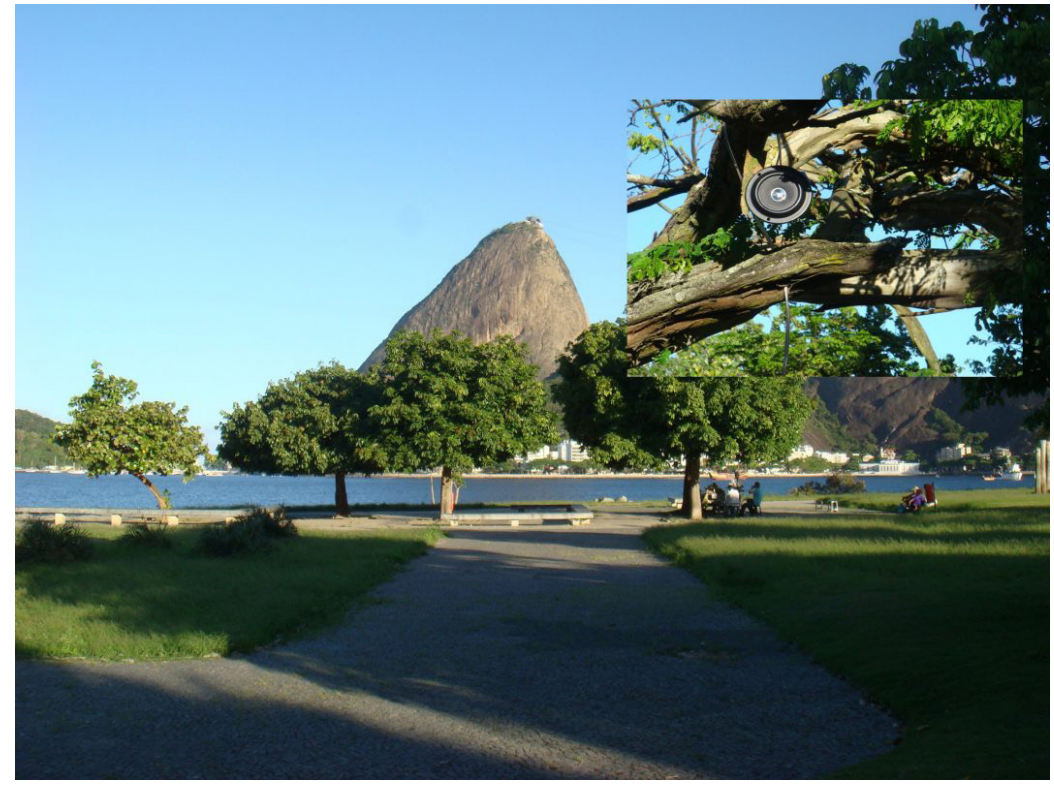

Figure 1: AFTER: Nature (2008): Sound installation with tweeters, $150 \mathrm{~m}$ cables, power, generator, track Credits: Saulo Laudares

\section{The Heartbeat eXHibition}

The sensation experienced during the exhibition of the work Heartbeat (2006), held in the stables of Parque Lage, in Rio de Janeiro, was of freedom and anguish at the same time. The vital sound of the heartbeats, which came out of the two huge speakers, made my body vibrate and I could not be exempt from those waves of severe. You could see the stars and the night. This experience that began in the body, reached other lines, other strata, flows, other areas of continuous intensity, other plateaus. It seemed that the audience was there to feel and nothing more. To try to explain this almost indescribable sensation I will use the words of Nietzsche in Zaratustra, in the aphorism Of those who despise the body: "I am body and soul - so speaks the child" (Nietzsche, 1973, p. 38). 
This aionic temporality emanates from sharing the Heartbeat sound facility, one of the fragments of the SoundSystem project, in which a conversation was heard between the hearts of artists Franz Manata and Saulo Laudares, on a dance floor, produced an effect that lasts for years. After I felt it, it was necessary to think about this experience ${ }^{2}$. The heart "is the organ of desire", of life, of the encounter, is a wishful heartbeat (Barthes, 2003, p. 91).

\section{INTENSIVE ENCOUNTERS}

The moment the notion of sharing appears in the SoundSystem project was in The Place in 1998. The Place is an open immersion space, in process since 1996, where manifestations occur that have in the other their sense of existence. The space can become a dance floor, an exhibition venue or lectures. The initial idea of The Place was to share the experience of the dance floor and was inspired by the work Incidents (Barthes, 2004), in the text At the Palace, tonight..., in which Barthes describes his experience at the French nightclub Le Palace which, at the time, was considered the Temple of Dance. Barthes, through his writing, refers to the power of this encounter. From then on, producing the intensity of the experience lived by Barthes became the focus of the duo.

The project itself arose from an encounter of the artists. Franz Manata and Saulo Laudares have been an artistic and affective partnership for more than twenty years. Both were born in Belo Horizonte but live in Rio de Janeiro since the year 2000. Franz Manata is a professor at the School of Visual Arts at Parque Lage and independent curator. He worked for seven years (2001-2008) as co-curator of the Museum of Modern Art of Rio de Janeiro. Saulo Laudares is a DJ of electronic music, in addition to developing soundtracks for dance performances and films. The works of the artists were part of the Artur Fidalgo gallery, located in Copacabana and, more recently, the Sé Gallery, which is in the center of São Paulo.

Inspired by Lygia Clark and Hélio Oiticica, they propose public participation. Oiticica and Clark put the spectator's physical presence in the center, overcoming the dissociation between feeling and knowing, mind and body, of the me and the other, of the producer and the consumer (Salomão, 2015, p. 73). The perspective of life as a laboratory experiment, by Oiticica, is a way of life that the duo has as a reference for the conception of their works. Consequently, in addition to the children of Oiticica, they are also sons of Nietzsche and Artaud (Salomão, 2015, p. 87). As for the influence of Lygia Clark, the notion of the artist's relational object foundation of the work of the duo, but the artists almost never make use of a material object, but of this dematerialized art, which is music. It is a relational art, which only exists in the event that is the encounter with the other.

\footnotetext{
' For Jacques Ranciére, in The sharing of the sensible (2005), sharing means both participation in a common set and, conversely, separation, distribution in installments. The sharing of the sensitive is a political act and refers to a discordant encounter of individual perceptions. There is a shared rhythm and, at the same time, a rhythm of each participant.

${ }^{2}$ According to Muniz Sodré (2016), etymologically, the word experience comes from the Latin, experiri, and is formed by ex (outside), peri (perimeter, limit) and entia (learning). It refers to the act of learning beyond the limits, of the borders, there is a spatial displacement, an adventure, a journey, a crossing, where the most important is the process, the duration, the becoming.
} 
In Experience and contemporary art (Kiffer, Bident \& Rezende, 2012), the notion of experience is presented through different perspectives. The experience is something that can cross us from side to side, to revolve, to transform us without being able to name it; is something that surpasses, that exceeds the language, that can not be contained and has nowhere to fit. The word experience has a double meaning, it names both a proof by which it passed as the purpose of producing or fostering. Experience is this point of indetermination between the singular and the universal, between the sensible and the intelligible, between the practical and the theoretical. According to Georges Bataille, experience is a threshold, it is not an accumulation of the lived, approaching more of the inexhaustible and non-formulable, referring to an inner experience, but a twisted interior, an exteriorized interior or an internalized exterior.

According to Claudio Oliveira, in the article How fire burns or of experience as a knowledge that is not known, "contemporary art may be an occasion for us to re-encounter with the constitutive non-knowledge of our humanity", to re-encounter with the intensive sensations (Kiffer, Bident \& Rezende, 2012, p. 42). After all, experience - including that of love - is born as a crack in the mirror, a breach in self-identity and in the ipseity or hecce ${ }^{3}$ of things, what Deleuze calls the unnameable, the untimely, that which is not a form, is a rhizome (Deleuze quoted in Kiffer, Bident \& Rezende, 2012, p. 85).

In the chapter "Essay on destruction of experience", in Childhood and history (Agamben, 2005), Agamben retakes Benjamin's Experiment and poverty (1933) and stresses that in order to impoverish the experience of man, a stressful daily life, which runs counter to singular temporality each one, will suffice. The experience, according to Agamben, would be a ladder that leads to other rooms in the house, a tool that intersperses present, past and future (Agamben, 2005, p. 24).

\section{THE CREATION OF A BODY WITHOUT ORGANS}

The experience of feeling the sound of heartbeats in Heartbeat, dissociated from a corporeal image, referred me to the Deleuzian concept of "body without organs" (BwO). These hearts were not there "exposed" in order to elucidate their physiological function in the body, fulfilling its utilitarian character in the organism. The intention was to share a desire to affect and be affected. The duo, Manata and Laudares, as well as Guatarri and Deleuze, share a mode of existence, a way of life, an ethics. The authors / artists do not write or create together, in the same rhythm, but each one in its time and thus work between the two, it is a double capture.

Deleuze and Guatarri work on the concept of BwO, in the third volume of $A$ thousand plateaus (1996). The BwO is a practice, an experiment, inspired by Antonin Artaud, an artist who sought to generate, during the theatrical experience, a body of resistance and intensity, free of automatisms and capable of dancing. The Theater of cruelty emphasized

${ }^{3}$ Daniel Lins, in the article "Joy as a revolutionary force", explains that a hecceidade is a specific individuation way that constitutes new individualities and resists to the identity prison governed by the ontological thought, through the connection of a set of heterogenous material elements, which Deleuze names of longitude and latitude, movement and rest, speed and slowness, rhizome, is not a form, is an unpublished and quick moving entity (Furtado \& Lins, 2008, p. 52). 
the sensitive and the sensations, problematizing the excess of rationality of the western world. The cruelty to Artaud was the lack of freedom (Lins, 1999, pp. 12-13). By emptying itself of its functionality, the body can open itself to the sensitive, to the event.

Deleuze and Guatarri appropriated Artaud's concept of BwO to name the need to create a body freed from its function, considering the logic of late capitalism, which prioritizes productivity and controls the time of individuals. The $\mathrm{BwO}$ is a body in happening, in becoming, a body capable of experiencing sensations, of dancing, of feeling joy and ecstasy.

A BwO is made in such a way that it can only be occupied, populated by intensities. Only the intensities pass and circulate, but the $\mathrm{BwO}$ is not a scene, a place, not even a support where something would happen. Nothing to do with a ghost, nothing to interpret. (...) It is not space and is not in space, it is matter that will occupy space in such or such degree. (Deleuze, 2007,p. 13)

The running routine due to the demands of productivity at work tends to anesthetize and desensitize our bodies and we must recreate them. Deleuze points to the importance of experimentation, as opposed to the interpretation of psychoanalysis (Deleuze, 2007, p. 11).

In the exhibition Freedom is little. What I want hasn't a name yet (2010), the curator Bernardo Mosqueira invited artists to think about contemporary freedom and exhibit their work at his home in the Botanical Garden. The phrase entitled the exhibition was taken from Clarice Lispector's book Near the wild heart (1980, p. 50). Franz Manata and Saulo Laudares presented The Place, which is the dance floor itself as a work of art. In a sound environment with the fluorescent wall, several DJs took turns in the sound. According to Mosqueira, "the dance floor is a place of political activity: resistance, affection, articulation, relationship and creation. Boil is Struggle".

The work Near the wild heart (Lispector, 1980), as well as the work of Manata and Laudares, deals with the invisible, the unspeakable, the sensations that the character experiences in her body, in her soul. The concepts of Spinoza, cross the work, as his indistinction between soul and body. Joana transgresses the repetitive quotidian of chronological time, playing with the time of the clock. She lives the instant through the invention of a subjective time. Joan creates for herself a body without organs, a body in becoming that does not have an identity, nor a defined gender, it is built.

Spinoza's sense of ethics, present both in the work of Lispector and in the duo, is to compose relationships that increase the power to act and to organize cheerful encounters that potentiate the force of existing. Spinoza is not surprised to have a body, but with what the body can: "bodies are not defined by their gender or species, by their organs and their functions, but by what they can, by the affections of which they are capable (Spinoza cit in Deleuze \& Parnet, 1998, p. 49).

The question that arises in the work of Manata and Laudares is how to extract something joyful and enthralling from what happens, a glimpse, an encounter, an event, a speed, a becoming (Deleuze \& Parnet, 1998, p. 54). So the important thing is to make 
an event, however small, the most delicate thing in the world, emphasizing alliances, nuptials, contagion, wind, almost imperceptible.

The body of the artists resists the chronopolitics, the politics of time control, besides resisting the insensibility, the impositions of genre and other forms of domestication of the desire. Artists want to be close to a free, wild heart.

\section{DANCING INSIDE OUT}

Orlandi, in Corporations in miniparade (2004, p. 10), emphasizes that $\mathrm{BwO}$ occur as magnetisations of escape lines that occur at the moments when they explode senses, in encounters wich one experiment in the body, intensities and eternity, in this aionic intertempor, the child' time, the duration of life. BwO is the field of immanence of desire.

Artaud's Theater of cruelty inaugurates a theater of non-representation, speaking to the senses, to the nervous system, to the flesh itself, to the skin. Artaud's whole body, neither human nor metaphysical, was a body of resistance and intensity, a body without organs. This body redone, reorganized and freed of its automatisms, opens to dance inside out. Dance is understood as the liberation of the body from its utilitarian movements, on the right way and inside out.

When they have obtained a body without organs, they will have freed it from their automatisms and returned their true freedom. Then they will be able to teach him to dance inside out as in the delirium of popular dances, and this reverse will be his true place. (Lins, 1999, p. 47)

This logic of feeling (Deleuze, 2007), thought by Deleuze, allows the unification of the opposing principles, the living and the dead, the awakened and the sleeping, the young and old, love and hate, caress and aggression, the man and the woman. The boundaries between the arts are blurred. In the plastic arts or music, it is not a question of reproducing or inventing forms, but of grasping the forces. It is by this bias that no art is figurative. The work of Manata and Laudares, by activating music and dance, seeks to make visible and sonorous things that are not. The work is immaterial and material at the same time.

In Logic of sense (Deleuze, 1974, p. 73), when Deleuze relates the literary work Alice in Wonderland to his theory of sense, he mentions the glorious body without organs, relating it to Dionysius, who shows his two countenances, his body open and lacerated, his head impassive and without organs, Dionysius dismembered but also impenetrable. The Body without Organs is this paradox of Carrol's work, it is this intensity, it is this limit. Saulo Laudares, referring to the work of the duo, relates it to "falling into a hole in Alice", referring to these "incoherent" sensations of the unconscious present in his artistic experiments.

We can determine our power to affect and be affected so that we do not live random encounters. If I do not know what my body is capable of, what the other body I am with is capable, and how our relationships can be composed, I live to capture the effects of 
these encounters. We can have the "mode of existence" that suits us, as Spinoza has shown (quoted in Deleuze, 2002).

In A thousand plateaus, on the plateau dated November 28, 1947, entitled How to create a body without organs (1996), Deleuze and Guatarri refer to the date Artaud created the concept, which can be found in the poem To end with the judgment of God. On this date, Artaud declares war on the organs (Deleuze \& Guatarri, 1996, p. 10). The point being made is that it is not about finding this ready body somewhere; you have to create it. The body without organs is an "exercise", is not a notion, but a set of practices, an experimentation. "The body without organs never concludes" (Gadelha, 2010, p. 3).

Deleuze, in The act of creation (1999) says that works will become works of art only if they become acts of resistance. They resist the annihilation of life and address the other, to another that does not exist (Deleuze 1999, p. 91). Art preserves, preserving a block of sensations, that is, a compound of percepts and affections. Percepts are perceptions that go beyond the state of those who have experienced them and affects overflow the feelings of those who have passed through them (Deleuze \& Guatarri, 2005, p. 213). Affection is experimentation, and not subject to interpretation, affection is non-personal (Furtado \& Lins, 2008, p. 45). In Dialogues (Deleuze \& Parnet, 1998), Deleuze points out that desire is not the privilege of an elite, it is itself a collective, a process that demands a meeting, an experience, a sharing.

The notion of Body without Organs, named by Artaud and used by Deleuze and Guatarri, is also called vibratile body (Rolnik, 2016), full body, upper body, impossible body, new body, body not oppressed, pure body, desiring body, intense body, powerful body, pulsating body, Dionysian body, dancing body, body that dances inside out. Importing your practice here.

What Deleuze and Guatarri propose in The anti-Oedipus (2011) is a desanalysis, making it possible to capture the power of the drug without drugging or the power of madness without being crazy. Schizoanalysis is this schizo process of decoding and deterritorialization (Deleuze, 2013, p. 35). Intensive is perceived as an act of resistance (Furtado \& Lins 2008, p. 69) and joy as a revolutionary force (Furtado \& Lins, 2008). Joy in this sense is enchantment, spell, state of grace, wandering. It is a vibrating joy, a desire for life, heraclitian joy-child or a dancer's joy (Furtado \& Lins, 2008, p. 49).

The sound, in Heartbeat (2006), potentiates the creation of this $\mathrm{BwO}$, by impelling the body to live the experience of dance. According to the curator and critic Guilherme Bueno (2012) wrote:

Heartbeat invests in what would be called "plastic sound", that is, the power of the waves to be able to shape, act on the participant's body, conferring a sculptural corporeity given less by the particular physical characteristics of space than by how much sound creates there fields of force of attraction or repulsion, causing us both to immerse hypnotically and in counterpart to be "obstructed" in that environment. (Bueno, 2012) 


\section{Circuits of AFFections}

As Safatle (2016) argued, societies are, in their fundamental dimension, circuits of affection. They build bonds through the way bodies are affected, sensed objects, and driven desires. These rare moments in which events cause us to be affected otherwise, break the circuits of affections that prevailed until then, dispossessing us of our paths, forsaking our rhythms and decomposing our bodies.

When Manata and Laudares invite people to participate in DJ performances, see an installation with the word Dancing in neon without music, listen to the Heartbeat installation or live the experience of contemplating nature and listening to birdsong during urban intervention AFTER: Nature, are performing an art of the Event. Here it is not important to produce objects that will be interpreted, but to experience the instant, the aionic become. To create, therefore, is not only to give shape to a matter or to reflect on it, but to construct ritornelos, crystals of time, in visual, sound, or linguistic materials (Zourabichvili, 2016, p. 148).

In the work, Deleuze: a philosophy of the event, Zourabichvili (2016) refers to the Logic of sense (1974), where Deleuze observed that we should not ask ourselves what the meaning of an event is, because the event is meaning itself! And the event is in not visible or non-tangible things, in abstract things like space and time.

The consistency of the world is in affection or sensation; in other words, it is in the event. But this event is not of the body, although it occurs to the bodies; it is at the limit of bodies, in the passage from one state of things to another (for example, to grow). Thus, because it is the incorporeal effect of mixtures of bodies, the event is expressible in nature, which makes language possible (Zourabichvili, 2016, p. 145).

In order for "affective triggers" to occur, new ways of perceiving, feeling, acting through art require something to "push" the thought, shake it and drag it in a search, there must be a chance incitement that depends on an encounter (Zourabichvili, 2016, p. 51). And an effective meeting is certainly not a fusion; it takes an art of distances, neither too close nor too far (Zourabichvili, 2016, p. 133).

\section{Aionic times}

In the essay "What is the contemporary?" (2010) Agamben investigates the problem of time and points out the need for the invention of another time, different from chronological time. It is from this experience of the invention of another temporality, of its own rhythm, of a joyful encounter with itself and with the other that we would like to deal with. The work of the artists Manata and Laudares flirts with this question in proposing a dilation and intensification of the experience of the lived time.

Emília Araújo, in When time disappears (2007), reflects on these issues of the rhythms of capitalist time and subjective time. The tools that mark the time, like the clock and the calendar, compel us to have a certain rhythm, which regulates our life. Individuals could not organize their day-to-day lives without being sure of the ways of measuring time. However, in other centuries, these rhythms were mismatched, for each society had its 
own temporal rhythm. But today, no society survives without the guidance of the same temporal system. This standardization of rhythms makes societies more dependent on each other, despite the geographical distances that separate them (Araújo, 2007, p. 21). Despite the usefulness of the calendar, the ability to assess the passage of time goes well beyond the ability to handle all these measuring instruments. We have the ability to feel the passage of time, which transforms the body and affects our state of mind.

Time, like space, is a physical dimension, but time, unlike space, is made up of the invisible. There is a marked impression of acceleration of time today. Studies of the use and occupation of time have shown that there is a growing "hunger for time", a result of the speed of the rhythms of life of individuals. The rush is a constant, everything must be fast and with few waiting times (Araújo, 2007, p. 24).

The conception of time as something external to the individual, which he must control and administer, is a principle of the constitution of modern society. The idea of an abstract and universal chronology as well. This is part of the process of global colonization of capital that needs to control individuals' time. However, it is imperative to assume that distinct rhythms develop at the same time (Araujo, 2007, 32).

Despite its immateriality, time has a profound capacity to affect people's behavior, and this objective and marketable time has consequences on the subjective experience of individuals, since the lack of time leads to stress, feelings of impatience and anxiety (Araújo, 2007, p. 37).

Individuals, even when they are not alone, cease to feel an integral part of a whole. In addition, there is a postponement of commitments in the biographical plan and the reduction of the amount of free time available. There is no doubt that time management has become a political issue (Araújo, 2007, p. 43).

The need to resist the current chronopolitics or the policy of optimization of time is justified in view of the current malaise present. The principle of performance governs the performance of the worker who must be available full time, which is made possible by the new communication technologies. There is, therefore, a refusal of the temporality of experience. According to the philosopher Matos (2007), there is this process of changing the temporality that is constituted through an acceleration of the present. The institutional organization of time causes each to lose the sense and command of the time of his life. The impossibility of having time to seek a meaning for its existence causes in man a feeling of non-belonging, of "feeling superfluous", "a stranger in the world". In this way, there is a loosening of the bonds, which become less durable. The haste accentuates the superficiality of the bonds, producing an interior impoverishment; given that feelings require duration to develop: "without stable ties, a symbolic deficit occurs in the individual and in society, since values depend on a shared space of shared experiences" (Matos, 2007, p. 102).

In the play The King-Time's Ship (1993), in which the philosopher Peter Pál Pelbart talks about the time of madness, the author seeks to rethink some of our temporal, aesthetic and existential closures, joking to undo certain crystallized orders in the mirror of time. The author seeks a "playful lightness" capable of reinventing everyday life. Pelbart 
quotes Paul Virilio to speak of a chronopolitics that is under way and whose unfoldings are still unknown, although it promotes a temporal flattening that provides a regime of temporality that tends to abolish the duration itself (Pelbart, 1993, p. 33). The author points out that while hegemonic chronopolitics aims at maximum acceleration, madness not only embodies a deceleration, but the claim of another time. And undoubtedly rescuing the "gushing of time" is a necessity not only for madness, but for our life and thought and it can be given through art. The proposal of the artists Manata and Laudares is to invent "workshops of time", seeking a long time, closer to the Bergsonian duration.

This space reserved for counter-time, the untimely is in The Place, place of imaginary immersion, a "time machine". The artists Manata and Laudares propose moments of resistance to the intrinsic violence of the current frenzied temporal regime and seek to rescue this aesthetic dimension of experiencing intensity, promoting a kind of "rhythmanalysis" (Pelbart, 1993), considering the rhythmic multiplicity of each subject. Electronic music mixes different voices, evokes diverse times and temporalities, where all are packed by the rhythm of the beats of a fast heart. There is here the proposal of the "between", of an "interlacing" (Santiago, 2000) in which one is not in the closure of the madness, that has an excess of the outside and of slowness of the time, nor totally within a system accelerated that does not makes room for creation.

Artists seek not the pulsed time of Chronos, but the floating time of poiesis found in Aion (Pelbart 1993, p. 80). To this attempt to "share the sensitive" (Rancière, 2005) or "how to live together", Barthes called "idiorrhythmia", a compound word for the word idios (proper) and rhythmos (rhythm), which was appropriated from the religious universe, but which can extend to the profane world. That way, despite living in community, the pace of each can take time. When referring to the duration of life, of vitality, of the aion, the pre-Socratic philosopher Heraclitus says: "duration of life is a child playing, moving parts in a game. The kingship is of the child" (Kahn, 2009, p. 95). And Nietzsche adds: "it is that the child is innocence and forgetfulness, a new beginning, a toy" (Nietzsche, 1973, p. 31).

In the "Aion" chapter, Deleuze discusses the two dimensions of time, that of Cronus and that of Aion, in Deleuze's work Logic of sense (Deleuze, 1974, pp. 90-93). According to Cronus, only the present exists in time and this present is somehow bodily. According to Aion, only the past and the future insist or subsist in time. While Cronus expressed the action of bodies and the creation of bodily qualities, Aion is the place of incorporeal events. While Cronos was inseparable from the bodies that filled it, Aion is populated with effects that inhabit it without ever filling it. This Aion' present, which represents the instant is the present of the actor, the dancer. The aion is "to withdraw from chronology without jumping into a beyond" (Pelbart, 2008, p. 22).

What, then, is time? It is the immediate connection of the heterogeneous, it is both the anonymous and the individuating, the impersonal and source of the whole identity (Zourabichvili, 2016, pp. 108-109). Deleuze's time is not one that values the connection of succession, it is a heterogeneous time, it is the time of the Event (Zourabichvili, 2016, p. 99). In a single organism, each organ has its present and its own duration, so that there coexist several presents, durations or relative speeds. Thus, each of us lives 
simultaneously in several lines of time, with some lines vanishing and brutally interrupting, while others affirm themselves. The present does not account for its own passage (Zourabichvili, 2016, 101). The third mode of time thought by Deleuze is a temporality that privileges neither the present, nor the past, but the future; all that exists is in becoming (Zourabichvili, 2016, p. 106).

\section{AFTER:NATURE}

An encounter, such as the event in AFTER: Nature (2008), allows one to escape into a new time dimension. This acousmatic sound system, in which the source of the sound was not seen, reproducing a track made up of sounds of bird songs, happened in full Aterro do Flamengo, in Rio de Janeiro. The project consisted of the installation of 42 tweeters in the canopy of five trees. In this work, the artists wished to attract people to this transmuter place, proposed a slowdown in urban chaos, instigated the through enjoying the sounds of birdsong and even allowed the most inattentive discover, through "failures" on track and other noises, that it was an artifice or device. In the words of curator Eduardo Campos on urban intervention "in the polyphony of cities, birdsong works as atavistic sound, reminding us nostalgically of nature, anti-civilization, the loss of Paradise" (Campos, 2008, p. 15). The work marks an interlude, situating itself as a work of passage.

We can think of this work as a file, a memory locus, the records of the past (Derrida, 2001), a "magic block", a child's toy, that triggers dormant sensations in our memory and reveals that the emergence of e-mail and of other forms of communication, have transformed our way of living and relating to public and private spaces. There is also the intention to reinvent everyday life and transfigure the commonplace. It is a denaturalization of the ordinary, what the French call dépaysement, an expression that describes the shift from one place to another and their effects from changes in habits and environment (Bueno, 2012). When artists mimic the sound of birdsong, they emphasize their power to allow us to feel and activate perceptions anesthetized by the hustle and bustle of the city.

This eternal time, with leisurely time, without hasty schedules, without obligations, refers to a joy of time without immediacy, another tantrum of time, a way of enjoying time different from the time of capitalism, as Waly Salomão affirms, "Is the time is pleasure", is the reign of pleasure and the suspension of the principle of reality, if only for a moment (Salomão, 2015, p. 90).

The sphere of duration experienced by music does not refer to a period of time - 10 minutes, half an hour or a fraction of a day - but a time experienced, the "now", a passage of the life we feel. Such a passage is measurable only in terms of sensitivities, tensions, and emotions. Our life is measured by rhythm, breath, and pulse. Listening to music can promote an "out of time" state (Langer, 2011, p. 28). According to Langer, whenever we feel, we are in the presence of Art, of aesthetic experience (Langer, 2011, pp. 116-117).

Our appropriation of space is sonorous. We recognize noises and the most diverse sounds and construct our affective memory from the domestic sounds, for example. 
Barthes announces that the freudian "ford-da" marks the birth of language when the child experiences the absence and presence of the mother with a game of throwing and retaking a reel tied in a string, creating not only the first symbolic game, but also the rhythm (Barthes, 1990, p. 220). Barthes also distinguishes between listening, which is a physiological phenomenon, of listening, which is a psychological act (Barthes, 1990, p. 217). And each one has his own personal symphony, constructed through experience.

\section{FinAL FRAGMENTS}

Manata and Laudares launch in the present-day small lights, like fireflies, which have their own light, but need the other to illuminate a larger portion of their time. Their art, through the device of music, awakens these dancing beings full of vitality, providing glimpses, "at once erotic, joyful and inventive" (Didi-Huberman, 2011, p. 20), a kind of "exception of innocent joy" (Didi-Huberman, 2011, p. 21) in a world in which time is so fast and without much time for poetry. This crucial place "where politics would incarnate in the bodies, gestures and desires of each" (Didi-Huberman, 2011, pp. 24-25) is undoubtedly a movement of resistance, perhaps very fragile and subtle, but necessary to illuminate our night. When Pasolini wrote about the fireflies he referred to the disappearance of the human at the heart of present-day society, he referred to a "malaise in culture". Didi-Huberman in this work entitled Survival of the fireflies makes an interference in this apocalyptic time and proposes a "politics of survival", of perception of the "new beauty of a choreography", of an invention of forms, of "rediscovering the childhood of the gaze on all the things" that can emit "parcels of humanity" (Didi-Huberman, 2011).

Translation: Priscilla Porto Nascimento Fasani

\section{REFERENCES}

Agamben, G. (2005). Infância e história: destruição da experiência e origem da história. Belo horizonte: Editora UFMG.

Agamben, G. (2010). O que é o contemporâneo? In G. Agamben, Nudez (pp. 19-29). Lisboa: Relógio D’ Água.

Araújo, E. (2007). O desaparecimento do tempo nas sociedades modernas. In E. Araújo \& A. Duarte (Eds.), Tempo e simultaneidade: o desaparecimento do tempo (pp.21-47). Porto: eCopy.

Barthes, R. (2003). Como viver junto: simulações romanescas de alguns espaços cotidianos: cursos e seminários no Collège de France, 1976-1977. São Paulo: Martins Fontes.

Barthes, R. (2004). Incidentes. São Paulo: Martins Fontes.

Barthes, R. (1990). O óbvio e o obtuso. Rio de Janeiro: Nova Fronteira.

Bataille, G. (1943). L'expérience intérieure. Paris: Gallimard.

Bueno, G. (2012, agosto). Franz Manata e Saulo Laudares. Dasartes, 23. Retrieved from http://dasartes.com. $\mathrm{br} /$ materias/franz-manata-e-saulo-laudares/ 
Campos, M. (2008). AFTER: Nature. In Catálogo Interferências Urbanas, prêmio 2008.

Deleuze, G. (1974). Lógica do sentido. São Paulo: Perspectiva, Ed. da Universidade de São Paulo.

Deleuze, G. (1999). O ato de criação. Palestra de 1987. Edição brasileira: Folha de São Paulo.

Deleuze, G. (2002). Espinosa uma filosofia prática. São Paulo: Editora Escuta.

Deleuze, G. (2007). Francis Bacon - lógica da sensação. Rio de Janeiro: Zahar.

Deleuze, G. (2013). Conversações. São Paulo: Editora 34.

Deleuze, G. \& Guatarri, F. (1996). Mil platôs: capitalismo e esquizofrenia, vol. 3. São Paulo: Ed. 34.

Deleuze, G. \& Guatarri, F. (2005). O que é filosofia? Rio de Janeiro: Ed. 34.

Deleuze, G. \& Guatarri, F. (2011). O anti-Édipo: capitalismo e esquizofrenia. São Paulo: Ed. 34.

Deleuze, G. \& Parnet, C. (1998). Diálogos. São Paulo: Escuta.

Derrida, J. (2001). Mal de arquivo: uma impressão freudiana. Rio de Janeiro: Relume Dumará.

Didi-Huberman, G. (2011). Sobrevivência dos vagalumes. Belo Horizonte: Editora UFMG.

Furtado, B. \& Lins, D. (Eds.). (2008). Fazendo rizoma. São Paulo: Hedra.

Gadelha, C. (2010). A respeito de modernos e contemporâneos. Anais VI Congresso da ABRACE, 11(1), 1-5. Retrieved from https://www.publionline.iar.unicamp.br/index.php/abrace/article/view/3358/3516

Kahn, C. (2009). A arte e o pensamento de Heráclito. São Paulo: Paulus.

Kiffer, A., Bident, C. \& Rezende, R. (ORG). (2012). Experiência e arte contemporânea. Rio de Janeiro: Editora Circuito.

Langer, S. K. (2011). Sentimento e forma: uma teoria da arte desenvolvida a partir de filosofia e nova chave. São Paulo: Perspectiva.

Lispector, C. (1980). Perto do coração selvagem. Rio de Janeiro: Editora Nova Fronteira.

Lins, D. (1999). Antonin Artaud, o artesão do corpo sem órgãos. Rio de Janeiro: Relume Dumará.

Matos, O. (2007). O mal-estar na contemporaneidade: performance e tempo. In M. Medeiros, M. Monteiro, \& T. Matsumoto (Eds.), Tempo e performance (pp. 11-20). Brasília: Editora de Pós-graduação em Arte da Universidade de Brasília.

Nietzsche, F. (1973). Assim falou Zaratustra. Lisboa: Guimarães Editores.

Orlandi, L. (2004). Corporeidades em minidesfile. Retrieved from http://www.pucsp.br/ nucleodesubjetividade/Textos/orlandi/corporeidade_minidesfiles.pdf

Pelbart, P. P. (1993). A nau do tempo-rei: sete ensaios sobre o tempo da Loucura. Rio de Janeiro: Imago.

Pelbart, P. P. (2008). O tempo não-reconciliado: imagens de tempo em Deleuze. São Paulo: Perspectiva.

Rancière, J. (2005). A partilha do sensível: estética e política. São Paulo: Editora 34. 
Rolnik, S. (2016). Cartografia sentimental: transformações contemporâneas do desejo. Porto Alegre: Editora Sulina; Editora da UFRGS.

Safatle, V. (2016). O circuito dos afetos: corpos políticos, desamparo e o fim do indivíduo. Belo Horizonte: Autêntica.

Salomão, W. (2015). Hélio Oiticica: qual é o parangolé? São Paulo: Companhia das Letras.

Santiago, S. (2000). Uma literatura nos trópicos. Rio de Janeiro: Rocco.

Sodré, M. (2016, August). Educação e diversidade [Lecture]. UFBA, 29 August 2016, Salvador, BA.

Zourabichvili, F. (2016). Deleuze: uma filosofia do acontecimento. São Paulo: Editora 34.

\section{BIOGRAPHICAL NOTE}

Priscilla Porto Nascimento Fasani holds a PhD in culture and society by the Federal University of Bahia (2019), M. D.in art science from University Federal Fluminense (2006) and graduated in Social Communication from the Pontifical Catholic University of Rio de Janeiro (2000). She published the book the Ethical relationship of art in the society of the spectacle by Uff publisher (2007). She is now member of the ECUS research Group of UFBA, since 2015.

ORCID: https://orcid.org/oooo-0002-1521-1818

Email: priscillafasani@hotmail.com

Address: Rua do Mangalo 277 - apto 102 - Patamares - Cep. 41.680-048 - Salvador - Bahia - Brasil

* Submitted: 01/09/2018

* Accepted: 10/2/2019 